\title{
Pengaruh Peraturan Perpajakan, Sosialisasi, dan Kepercayaan atas Sistem Perpajakan terhadap Kemauan Pelaksanaan Tax Amnesty (Studi Empiris Wajib Pajak Orang Pribadi di Kabupaten Bekasi)
}

\author{
Kristina Sepma Sipahutar \\ kristinasepmarona@gmail.com \\ Accounting Program Study, Faculty of Business \\ Universitas Presiden, Cikarang, Indonesia \\ Whereson Siringoringo \\ wheresonringo@gmail.com \\ Accounting Program Study, Faculty of Business \\ Universitas Presiden, Cikarang, Indonesia
}

\begin{abstract}
The implementation of tax amnesty is one of the ways implemented by the government to increase tax revenue and to increase taxpayer compliance, where taxpayers are willing to disclose assets and pay the ransom on assets that have not been reported by taxpayers. This study aims to determine the effect of tax regulations, tax socialization, trust in the taxation system on the willingness of taxpayers to implement tax amnesty. This study makes an individual taxpayer in Bekasi Kabupaten as an object. This study uses a quantitative approach and data collection methods using a questionnaire to 110 samples of respondents with a nonprobability sampling approach. The data analysis method used is multiple linear regression analysis. The results of the study concluded that the taxation variable has a positive influence on the willingness of taxpayers in implementing tax amnesty, the taxation socialization variable does not affect the willingness of taxpayers to carry out tax amnesty, and the variable trust in the taxation system has a positive effect on the willingness of taxpayers in carrying out tax amnesty.
\end{abstract}

Keywords: tax amnesty, tax regulations, tax socialization, trust in the taxation system.

\section{Intisari}

Pelaksanaan tax amnesty merupakan salah satu cara yang diterapkan oleh pemerintah untuk meningkatkan penerimaan perpajakan serta untuk meningkatkan kepatuhan wajib pajak, dimana wajib pajak agar mau melakukan pengungkapan harta dan membayar tebusan atas harta yang selama ini belum dilaporkan oleh wajib pajak. Penelitian ini bertujuan untuk mengetahui pengaruh peraturan perpajakan, sosialisasi perpajakan, kepercayaan kepada sistem perpajakan terhadap kemauan wajib pajak dalam melaksanakan tax amnesty. Penelitian ini menjadikan Wajib Pajak Orang Pribadi yang berada di Kabupaten Bekasi sebagai objek. Penelitian ini menggunakan pendekatan kuantitatif dan metode pengumpulan data menggunakan kuesioner terhadap 110 sampel yang menjadi responden dengan pendekatan non probability sampling. Metode analisis data yang digunakan adalah analisis regresi linear berganda. Hasil penelitian menyimpulkan bahwa variabel peraturan perpajakan memiliki 
pengaruh yang positif terhadap kemauan wajib pajak dalam melaksanakan tax amnesty, variabel sosialisasi perpajakan tidak berpengaruh terhadap kemauan wajib pajak dalam melaksanakan tax amnesty, dan variabel kepercayaan terhadap sistem perpajakan memiliki pengaruh yang positif terhadap kemauan wajib pajak dalam melaksanakan tax amnesty.

Kata kunci: tax amnesty, peraturan perpajakan, sosialisasi perpajakan, kepercayaan terhadap sistem perpajakan.

\section{PENDAHULUAN}

Pasal 1 ayat (1) Undang-Undang Nomor 28 Tahun 2007 mendefiniskan bahwa, pajak merupakan kontribusi yang terutang oleh wajib pajak yang bersifat memaksa kepada negara dengan tujuan untuk meningkatkan kemakmuran masyarakat dan dipergunakan sebagai sumber dana untuk pembiayaan pemerintahan, seperti untuk membiayai pembangunan, belanja pegawai, belanja barang dan pemeliharaan sebagaimana fungsi pajak sebagai budgetair.

Dwijayanti dan Hamidah (2017), mengatakan bahwa dalam memaksimalkan penerimaan negara yang berasal dari sektor pajak serta untuk meningkatkan kepatuhan wajib pajak, pemerintah mengeluarkan kebijakan tax amnesty dengan tujuan utamanya adalah untuk memasukkan kembali ke dalam negeri investasi atau dana-dana milik Wajib Pajak yang berada di luar negeri, sehingga dana tersebut dapat digunakan untuk menunjang penerimaan negara dalam membiayai keperluan negara. Rahayu (2016) menjelaskan bahwa Tax amnesty merupakan penghapusan pajak tanpa adanya sanksi administrasi maupun pidana dengan tujuan agar wajib pajak berkeinginan mengungkapkan harta dengan benar dan membayar uang tebusan.

Tax amnesty ditetapkan melalui Undang-Undang Nomor 11 Tahun 2016 yang resmi diimplementasikan tanggal 18 Juli 2016. Namun upaya tersebut belum optimal karena realisasi penerimaan tax amnesty masih di bawah target yang ditentukan. Hasil pendaftaran program tax amnesty telah ditutup pada tanggal 31 Maret 2017 dapat dilihat seperti berikut ini:

Tabel 1. Target dan realisasi

\begin{tabular}{|c|c|c|c|c|}
\hline No. & Keterangan & $\begin{array}{l}\text { Target Penerimaan } \\
\text { (Dalam Triliun Rupiah) }\end{array}$ & $\begin{array}{l}\text { Realisasi } \\
\text { (Dalam Triliun Rupiah) }\end{array}$ & Persentase \\
\hline 1. & Deklarasi & 4.000 & 4.707 & $117,68 \%$ \\
\hline 2. & Repratriasi & 1.000 & 147 & $14,70 \%$ \\
\hline 3. & Uang Tebusan & 165 & 114 & $69,09 \%$ \\
\hline
\end{tabular}

Sumber : https://www.finance.detik.com/ tanggal 5 Mei 2017

Data pada Tabel 1 di atas dapat menjelaskan bahwa, meskipun hasil deklarasi harta dari dalam negeri dan deklarasi harta dari luar negeri melebihi target, namun untuk realisasi repratriasi dan uang tebusan masih belum mencapai target. Terlebih untuk realisasi repatriasi masih sangat jauh dari target yakni tercapai kurang dari 15\% dari target pemerintah sebesar Rp. 1.000 triliun.

Menurut Sukmana (2017), salah satu penyebab tidak terealisasinya adalah karena jumlah wajib pajak baru yang mengikuti tax amnesty masih terlalu kecil karena harta Wajib Pajak lebih banyak disimpan di negara lain. Sementara jumlah yang dilaporkan hanya Rp. 1.179

DOI: http://dx.doi.org/10.33021/jaaf.v3i2.939 


\section{JAAF (Journal of Applied Accounting and Finance) Volume 3, Number 2, 2019, 79-95}

triliun. Padahal potensi harta wajib pajak yang disimpan di negara lain mencapai Rp. 11.000 triliun.

Target pemerintah untuk peserta yang mengikuti tax amnesty adalah sebanyak 2 juta wajib pajak namun kenyataannya total peserta tax amnesty hanya mencapai 972.530 wajib pajak saja (Ariyanti, 2017). Khusus untuk tambahan baru mencapai 52.757 wajib pajak. Menurut Direktorat Jenderal Pajak (Ditjen Pajak) Kementerian Keuangan memastikan, 52.757 wajib pajak baru telah diperoleh dari program tax amnesty, namun belum mampu menambah penerimaan pajak seperti yang diharapkan di tahun 2017. Apabila dilihat dari jumlah wajib pajak baru yang mengkuti tax amnesty, hasil tax amnesty sulit untuk memberikan efek jangka panjang terutama terhadap penerimaan negara.

Realisasi jumlah wajib pajak baru, deklarasi, repatriasi, dan uang tebusan yang tidak mencapai target mengindikasikan bahwa kemauan wajib pajak untuk melaksanakan tax amnesty masih rendah. Yani dan Noviari (2017) menjelaskan bahwa kemauan untuk mengikuti tax amnesty merupakan pilihan wajib pajak untuk mau atau tidak mau untuk mendukung program tersebut, sehingga bersedia mengungkapkan dan/atau mengembalikan dana-dana yang disimpan di luar negeri ke Indonesia. Menurut Hardiningsih dan Yulianawati (2011) kemauan wajib pajak dalam membayar pajak adalah perilaku wajib pajak terhadap pajak tersebut.

Selain kemauan, regulasi di suatu negara juga mempengaruhi wajib pajak dalam melaksanakan tax amnesty seperti yang di ungkapkan oleh Menteri Keuangan (Menkeu) dimana sebagian wajib pajak beralasan karena regulasi di negara tempat mereka menyimpan harta di luar negeri masih menyulitkan untuk menarik hartanya supaya bisa diinvestasikan ke dalam negeri. Sebagian lagi, karena ternyata dana repatriasi yang dilaporkan itu bukan dana likuid, sehingga menunggu proses untuk diubah jadi tunai, atau menunggu pencairan atau jatuh tempo untuk yang berbentuk deposito (https://www.kominfo.go.id/, 3 April 2017, diakses pada tanggal 21 Desember 2018).

Sembiring (2017) menjelaskan bahwa, penerimaan pajak masih rendah dikarenakan kurangnya sosialisasi yang dilakukan oleh Direktorat Jenderal Pajak (Ditjen Pajak) kepada masyarakat. Sosialisasi perpajakan bertujuan untuk memberikan pengetahuan mengenai tata cara dan metode perpajakan kepada masyarakat khususnya wajib pajak (Rohmawati et al. 2013). Pelaksanaan tax amnesty juag harus ditunjang dengan sosialisasi tentang bagaimana hak dan kewajiban wajib pajak dapat terlaksana dengan baik dalam mengikuti program tax amnesty tersebut, sehingga setiap wajib pajak dapat memahami dan mengerti program tax amnesty tersebut dan tidak muncul kebingungan maupun kesalahan yang mungkin dapat dilakukan oleh wajib pajak pada saat melaksanakan program tersebut.

Selain masalah sosialisasi tersebut, Pengamat Ekonomi Indef Bhima Yudhistira menuturkan, bahwa masalah yang ada di lingkungan pajak pun membuat berkurangnya kepercayaan masyarakat, sehingga menurunkan minat masyarakat. Berbagai kasus di internal pajak seperti suap pajak menurunkan kepercayaan masyarakat untuk ikut tax amnesty (Sembiring 2017). Apabila persepsi atas sistem amnesti pajak baik maka dapat meningkatkan kepercayaan terhadap sistem perpajakan sehingga memengaruhi kemauan wajib pajak dalam membayar pajak (Yani dan Noviari, 2017).

Dari penjelasan di atas, maka penelitian ini bertujuan: (1) untuk mengetahui pengaruh peraturan perpajakan terhadap kemauan wajib pajak dalam melaksanakan tax amnesty; (2) untuk mengetahui pengaruh sosialisasi perpajakan terhadap kemauan wajib pajak dalam melaksanakan tax amnesty; (3) untuk mengetahui pengaruh kepercayaan atas sistem perpajakan terhadap kemauan wajib pajak dalam melaksanakan tax amnesty. 


\section{KAJIAN TEORI}

\section{Teori Atribusi}

Teori yang dikembangkan oleh Fritz Heider tahun 1958 beragumentasi bahwa perilaku seseorang ditentukan oleh kombinasi antara kekuatan internal (internal forces), yaitu faktorfaktor yang berasal dari dalam diri seseorang, seperti kemampuan atau usaha, dan kekuatan eksternal (external forces), yaitu faktor-faktor yang berasal dari luar, seperti kesulitan dalam pekerjaan atau keberuntungan (Lubis dan Arfan 2011). Robbins et al. (2015) menegaskan bahwa dalam teori atribusi, pengamatan perilaku individu ditentukan menjadi faktor internal dan eksternal.

Penentuan faktor internal dan eksternal menurut (Robbins et al. 2015) tergantung pada tiga faktor yaitu: (a) Kekhususan. Kekhususan merupakan pengamatan ketidakbiasaan perilaku individu dalam situasi tertentu. Penilaian atribusi eksternal ketika perilaku individu tidak biasa, sebaliknya atribusi internal jika perilaku dianggap wajar; (b) Konsensus. Konsensus diartikan kesamaan cara pandang pengamatan banyak orang atas perilaku individu dalam situasi yang sama. Penilaian atribusi eksternal jika memiliki konsensus tinggi, sebaliknya atribusi internal jika konsensus rendah; dan (c) Konsistensi. Konsistensi diartikan penilaian perilaku individu dengan respon sama dalam kurun sekian waktu. Semakin konsisten perilaku tersebut, maka dinilai atribusi internal, sebaliknya semakin tidak konsisten maka dinilai atribusi eksternal.

Teori ini dapat memberikan penjelasan latar belakang masalah yang disajikan dalam penelitian ini. Perilaku wajib pajak dipengaruhi oleh faktor eksternal dan internal dari wajib pajak itu sendiri, apakah akan melakukan atau tidak melakukan tax amnesty atas dana atau harta wajib pajak yang seblumnya belum pernah diungkapkan dalam laporan SPTnya. Wajib pajak akan memutuskan untuk melakukan atau tidak melakukan tax amnesy mana kala wajib pajak melihat adanya pengaruh dari luar dan dalam diri wajib pajak yang dapat dijadikan dasar untuk pengambilanl keputusannya, diantaranya peraturan yang jelas tentang pelaksanaan tax amnesty, perolehan sosialisasi tentang peraturan tax amnesty dan juga kepercayaan wajib pajak terhadap program tax amnesty yang dijalankan oleh pemerintah.

\section{Pajak}

Pajak didefinisikan dalam Undang-Undang No. 28 Tahun 2007 tentang Perubahan Ketiga Atas Undang-Undang No.6 Tahun 1983 tentang ketentuan umum dan tata perpajakan, sebagai kontribusi wajib kepada negara yang terutang oleh orang pribadi atau badan yang bersifat memaksa berdasarkan Undang-Undang, dengan tidak mendapatkan imbalan secara langsung dan digunakan untuk keperluan negara bagi sebesar-besarnya kemakmuran rakyat.

Awlia dan Siringoringo (2019) menjelaskan bahwa pajak merupakan bentuk peran serta wajib masyarakat dalam membiayai keperluan negara dan terutang oleh orang pribadi atau badan yang diselenggarakan berdasarkan undang-undang sebagai bukti keikutsertaan warga negara dalam mewujudkan pembangunan nasional. Oleh karena itu pajak merupakan bentuk tanggungjawab warga negara dalam pembiayaan dan pembangunan nasional yang pelaksanaannya telah ditentukan dan diatur dalam undang-undang.

\section{Tax Amnesty}

Menurut Undang-Undang Nomor 11 Tahun 2016 Tentang Pengampunan Pajak, tax amnesty adalah penghapusan pajak yang seharusnya terutang, tidak dikenai sanksi administrasi perpajakan dan sanksi pidana dibidang perpajakan, dengan cara mengungkap harta dan membayar uang tebusan. Huslin dan Ngadiman (2015) mengatakan, Tax amnesty 
adalah suatu kesempatan waktu yang terbatas pada kelompok pembayar pajak tertentu untuk membayar sejumlah tertentu dan dalam waktu tertentu berupa pengampunan kewajiban pajak (termasuk bunga dan denda) yang berkaitan dengan masa pajak sebelumnya atau periode tertentu tanpa takut hukuman pidana.

Program tax amnesty terbagi dalam 3 (tiga) periode, yaitu: Periode I (dari tanggal diundangkan - 30 September 2016), Periode II (1 Oktober 2016 - 31 Desember 2016), dan Periode III (1 Januari 2017 - 31 Maret 2017), yang dibagi menjadi dua bagian, yitu repatriasi dan deklarasi. Repatriasi adalah kondisi dimana wajib pajak bermaksud mengalihkan hartanya ke Indonesia (Muzammil, 2016:96). Deklarasi adalah ketika wajib pajak mengungkapkan hartanya yang berada di wilayah Indonesia dan tidak dapat mengalihkan harta ke luar negeri paling singkat selama tiga tahun terhitung sejak diterbitkannya surat keterangan.

\section{Peraturan Perpajakan}

Peraturan Perpajakan adalah peraturan tertulis yang memuat norma hukum yang mengikat secara umum dan dibentuk atau ditetapkan oleh lembaga negara atau pejabat yang berwenang melalui prosedur yang ditetapkan dalam Peraturan Perundang-undangan (Marzuki 2016). Pasal 8 ayat 6 dan 7 UU No. 11 tahun 2016 sebagai dasar hukum tax amnesty yakni wajib pajak bermaksud mengalihkan Harta dan menginvestasikannya ke Indonesia paling singkat selama jangka waktu 3 (tiga) tahun dan 31 Maret 2017 wajib pajak yang memilih menggunakan tarif Uang Tebusan tidak dapat mengalihkan Harta ke luar negeri paling singkat selama jangka waktu 3 (tiga) tahun terhitung sejak diterbitkannya Surat Keterangan.

Permenkeu No. 119/PMK.08/2016 tentang Cara Pengalihan Harta wajib pajak ke dalam Wilayah Negara Kesatuan Republik Indonesia Pasal 2 menentukan bahwa tax amnesty diberikan kepada wajib pajak yang melakukan pengungkapan Harta yang dimilikinya dalam Surat Pernyataan, meliputi Harta yang berada di dalam wilayah Negara Kesatuan Republik Indonesia; dan/atau Harta yang berada di luar wilayah Negara Kesatuan Republik Indonesia. Selain itu, Tambahan Harta dan Utang yang membentuk nilai Harta bersih yang dilaporkan dalam Surat Pernyataan dan telah diterbitkan Surat Keterangan diperlakukan sebagai perolehan Harta baru dan perolehan utang baru wajib pajak sesuai tanggal Surat Keterangan.

\section{Sosialisasi Perpajakan}

Sosialisasi Perpajakan adalah kegiatan fiskus pajak dalam memberikan pengetahuan kepada wajib pajak mengenai segala hal tentang perpajakan, baik peraturan maupun tata cara perpajakan melalui metode-metode yang tepat (Rimawati 2013). Jika sosialisasi secara rutin dilakukan dan diikuti oleh wajib pajak maka akan dapat meningkatkan pengetahuan wajib pajak mengenai aturan-aturan perpajakan (Trisnasari et al. 2017).

Menurut Mustofa et al (2016) menjelaskan bahwa sosialisasi adalah suatu konsep umum yang dimaknakan sebagai proses dimana kita belajar melalui interaksi dengan orang lain, tentang cara berfikir, merasakan dan bertindak dimana kesemuanya itu merupakan hal-hal yang sangat penting dalam menghasilkan partisipasi sosial yang efektif. Dari pengertian diatas, dapat diambil kesimpulan bahwa sosialisasi perpajakan merupakan suatu upaya dari Dirjen Pajak untuk memberikan pengertian, informasi dan pembinaan kepada masyarakat pada umumnya dan wajib pajak pada khususnya mengenai segala sesuatu yang berhubungan dengan perpajakan dan perundang-undangan.

Sosialisasi kepada calon wajib pajak merupakan hal yang sangat penting untuk dilakukan oleh pemerintah, agar para calon wajib pajak mampu mengetahui dengan baik hak dan 
kewajiban yang harus dilaksanakan agar sesuai dengan peraturan dan perundang-undangan yang berlaku dan juga untuk menciptakan wajib pajak yang memiliki karakter yang patuh. Keberhasilan sosialisasi perpajakan adalah meningkatnya kepatuhan wajib pajak untuk memenuhi kewajiban perpajakannya. Dalam meningkatkan kesadaran dan pengetahuan masyarakat khususnya wajib pajak dalam bidang perpajakan maka sangat diperlukannya sosialisasi, sehingga wajib pajak memiliki kesadaran akan perlunya keberadaan pajak bagi negara dan pada akhirnya akan menyebabkan peningkatan penerimaan pajak.

\section{Kepercayaan Atas Sistem Perpajakan}

Kepercayaan terhadap sistem perpajakan merupakan penilaian masyarakat akan keberhasilan sistem perpajakan dalam mewujudkan kesejahteraan rakyatnya sesuai dengan Undang-Undang yang berlaku (Probondari, 2013). Dengan sistem perpajakan yang baik, akan berdampak pada kemauan wajib pajak dalam melaksanakan setiap kewajiban pajak mereka karena partisipasi wajib pajak untuk memaksimalkan target pajak adalah pokok utama dalam sistem penerimaan pajak itu sendiri dan tidak satupun sistem perpajakan dapat berfungsi dengan efektif tanpa peran serta sebagian besar wajib pajak.

Menurut Kirana \& Moordiningsih, (2010) mengatakan bahwa membangun kepercayaan pada orang lain merupakan hal yang tidak mudah. Kepercayaan terbentuk melalui rangkaian perilaku antara orang yang memberikan kepercayaan dan orang yang dipercayakan tersebut. Kepercayaan muncul dari pengalaman dua pihak yang sebelumnya bekerja sama dalam sebuah kegiatan atau organisasi. Pengalaman ini memberikan kesan positif bagi kedua pihak sehingga mereka saling mempercayai dan tidak berkhianat, yang dengan itu dapat merusak komitmen.

Sistem perpajakan juga harus dibangun dengan baik agar mampu melaksanakan kepercayaan yang telah diberikan oleh publik melalui pemerintah untuk dapat melaksanakan tugas dan fungsi yang dipercayakan kepada, dan dengan demikian maka sistem perpajakan akan mampu menciptakan kepatuhan wajib pajak karena mampu menjalankan kepercayaan publik dalam mengelola perpajakan di Indonesia sebagai asas timbal baliknya.

\section{Kemauan Wajib Pajak Dalam Melaksanakan Tax Amnesty}

Kemauan wajib pajak merupakan suatu bentuk dorongan dari dalam diri seseorang, yang diputuskan berdasarkan pertimbangan pikiran dan perasaan yang menimbulkan suatu tindakan untuk dapat mencapai tujuan tertentu. Kemauan untuk melaksanakan tax amnesty dapat diartikan sebagai suatu tindakan dari setiap wajib pajak untuk mau berperan serta dalam memberikan kontribusinya untuk melaksanakan (ditetapkan dengan peraturan) pengungkapan harta yang selama ini belum pernah dilaporkan di dalam SPT dan membayarkan uang tebusannya, yang digunakan untuk membiayai pengeluaran umum negara dengan tidak mendapat jasa timbal (kontraprestasi) secara langsung (Rantung dan Adi 2009).

Kemauan wajib pajak merupakan sifat yang paling penting dari dalam diri wajib pajak dalam melaksanakan program pengampunan pajak. Oleh karena itu, sangat penting apabila kemauan melaksanakan pengampunan pajak oleh wajib pajak dapat timbul dari dalam diri individu secara sukarela, dengan tidak ada paksaan dari pihak manapun sesuai dengan Undang-undang yang telah ditetapkan.

\section{Perumusan Hipotesis}

Beberapa peraturan di negara di tempat dmana wajib pajak menyimpan hartanya di luar negeri, masih menyulitkan untuk menarik hartanya agar dapat diinvestasikan ke dalam negeri dan sebagian wajib pajak memiliki dana repatriasi yang dilaporkan bukan merupakan dana 
likuid maka perlu menunggu proses untuk diubah jadi tunai, atau menunggu pencairan atau jatuh tempo untuk yang berbentuk deposito sehingga peraturan perpajakan tidak mudah untuk dilaksanakan oleh wajib pajak karena berbenturan dengan peraturan perpajakan diluar negeri. Peraturan perpajakan yang mudah dan tidak menyulitkan wajib pajak, di duga akan membuat wajib pajak mau untuk melaksanakan tax amnesty.

Sosialisasi perpajakan dapat memberikan pengetahuan dan wawasan kepada wajib pajak mengenai tax amnesty baik peraturannya maupun tata caranya. Dengan adanya sosialisasi berupa penyuluhan, Informasi langsung dari petugas (fiskus) ke wajib pajak atau melalui media cetak dan elektronik akan meningkatkan pengetahuan wajib pajak mengenai tax amnesty sehingga di duga akan membuat wajib pajak mau untuk melaksanakan tax amnesty.

Banyaknya aparat pajak yang belum memberikan kinerja yang baik menyangkut jasa pelayanan publik kepada masyarakat dan wajib pajak belum mendapatkan keadilan dalam memperoleh hak dan pelayanan yang sama sehingga membuat kepercayaan masyarakat menurun sedangkan apabila seluruh aparat pemerintah meningkatkan dan memperbaiki mutu pelayanannya serta menjamin keadilan yang setara pada setiap wajib pajak maka akan membuat kepercayaan masyarakat meningkat. Oleh karena itu, kepercayaan di duga berpengaruh terhadap kemauan wajib pajak dalam melaksanakan tax amnesty.

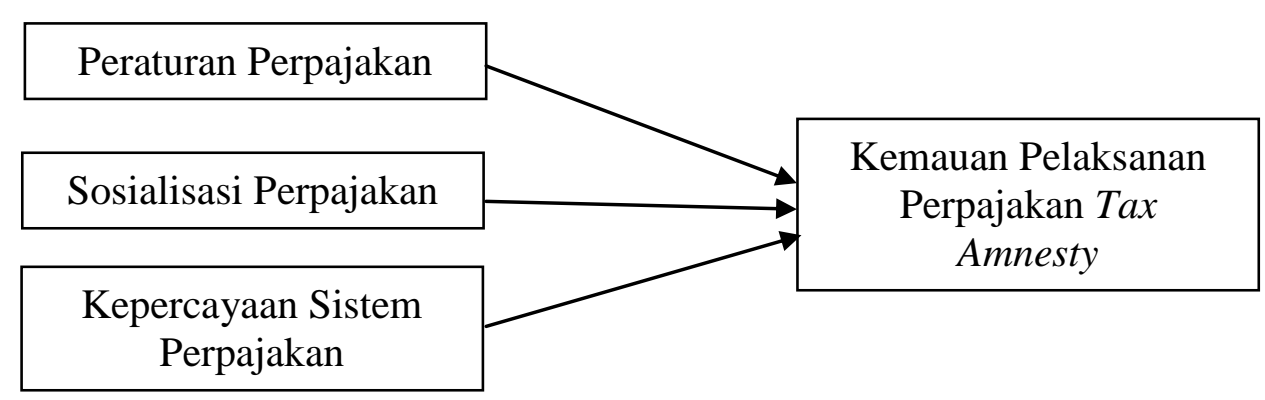

Gambar 1. Kerangka Pemikiran Teoritis

$H_{1}$ : $\quad$ Peraturan perpajakan berpengaruh terhadap kemauan wajib pajak dalam melaksanakan tax amnesty.

$\mathrm{H}_{2}$ : $\quad$ Sosialisasi perpajakan berpengaruh terhadap kemauan wajib pajak dalam melaksanakan tax amnesty

H3: Kepercayaan terhadap sistem perpajakan berpengaruh terhadap kemauan wajib pajak dalam melaksanakan tax amnesty

\section{METODE PENELITIAN}

Jenis penelitian menggunakan pendekatan kuantitatif, yaitu metode ilmiah untuk mendapatkan data yang valid dengan tujuan dapat menemukan, membuktikan dan mengembangkan suatu pengetahuan sehingga pada gilirannya dapat digunakan untuk memahami, memecahkan dan mengantisipasi masalah dalam bidang tertentu (Sugiyono, 2012).

Variabel dalam penelitian ini terbagi atas 2 yaitu, variable bebas dan variabel terikat. Variabel bebas terdiri atas Variabel peraturan perpajakan, variabel Sosialisasi dan variabel

DOI: http://dx.doi.org/10.33021/jaaf.v3i2.939 
kepercayaan atas sistem perpajakan. Variabel terikat dalam penelitian ini adalah variabel tax amnesty. Variabel peraturan perpajakan dalam penelitian ini dibatasi pada undang-undang yang mengatur tentang Tax amnesty, yaitu Undang-undang nomor 11 tahun 2016. Sosialisasi Perpajakan adalah kegiatan fiskus pajak dalam memberikan pengetahuan kepada wajib pajak mengenai segala hal tentang perpajakan, baik peraturan maupun tata cara perpajakan melalui metode-metode yang tepat (Rimawati, 2013). Kepercayaan terhadap sistem perpajakan dapat diartikan sebagai penilaian masyarakat akan keberhasilan sistem perpajakan dalam mewujudkan kesejahteraan rakyatnya sesuai dengan Undang-Undang yang berlaku (Probondari, 2013). Variabel bebas ini akan diturunkan dalam bentuk pernyataan yang diukur dengan menggunakan skala likert

Data yang digunakan adalah data primer, menurut (Sugiyono, 2012), data primer adalah data yang diperoleh langsung dari responden atau informan. Menurut (Arikunto, 2013) data primer adalah data yang dikumpulkan melalui pihak pertama, biasanya dapat melalui wawancara, jejak dan lainnya. Data Primer diperoleh melalui hasil penyebaran kuisioner kepada sejumlah responden Wajib Pajak Orang Pribadi (WPOP) yang berdomisili di Kabupaten Bekasi. Dengan menggunakan metode pengambilan Convenient Sampling. Menurut (Sugiyono, 2012) Convenient Sampling adalah penentuan sampel berdasarkan aksidental (kebetulan) dan bersedia menjadi responden. Alasannya untuk mempermudah pengambilan sampel penelitian karena jumlah populasi yang tidak diketahui.

Menurut Uma Sekaran (2006) bahwa jumlah sampel yang memadai dalam penelitian adalah antara 30 hingga 500 responden. Menurut Ferdinand (2006) mengatakan jumlah sampel adalah jumlah indikator dikali 5 hingga 10, jumlah sample yang akan diuji pada penelitian ini sebanyak $10 \mathrm{kali}$ dari jumlah indikator dimana jumlah indikator dalam penelitian ini sebanyak 11 indikator sehingga jumlah sampel yang akan diuji sebanyak $10 \times$ $11=110$ sampel.

Instrumen kuesioner dibuat untuk dapat mengukur variabel penelitian, agar dapat instrumen dapat diandalkan maka kuesioner yang dibuat maka harus dilakukan pretest diuji terlebih dahulu dengan menggunakan uji validitas dan realibilitas. Ghozali (2009) menjelaskan bahwa uji validitas adalah uji yang dilakukan untuk mengukur sah atau tidaknya pernyataan yang digunakan dalam kuesioner. Kuesioner dikatakan valid jika pertanyaan dalam kuesioner mampu mengungkapkan sesuatu yang akan diukur oleh kuesioner tersebut yaitu apabila nilai $t$ hitung $>t$ tabel. Sekaran (2006) menjelaskan bahwa, Uji reliabilitas dilakukan untuk pernyataan yang telah melalui pengujian validitas dan dinyatakan valid. Pengujian reliabilitas ini dilakukan untuk mengetahui sejauh mana suatu alat pengukur dapat dipercaya atau dapat diandalkan apakah akan tetap konsisten apabila dilakukan dengan dua atau lebih terhadap gejala yang sama dengan alat ukur yang sama, jika variabel memiliki nilai Cronbach's Alpha diatas 0,60 maka variabel tersebut dapat dinyatakan reliabel, dan sebaliknya (Sugiyono, 2012).

\section{Teknik Analisis}

Analisis yang diterapkan dalam penelitian ini adalah analisis regresi linear berganda. Agar data yang telah diperoleh dapat dianalisis, maka harus terlebih dahulu memenuhi syarat uji asumsi klasik yang terdiri atas uji normalitas, uji multikolinearitas, uji heterskedastisitas. Menurut (Santoso 2013) analisis regresi linear berganda digunakan apabila menguji pengaruh searah dan variabel bebas lebih dari satu. Persamaan formulasi regresi sebagai berikut:

$$
Y=a+b_{1} x_{1}+b_{2} x_{2}+. .+b_{n} x_{n}
$$

DOI: http://dx.doi.org/10.33021/jaaf.v3i2.939 
Uji T bertujuan untuk mengetahui pengaruh variabel-variabel bebas secara parsial atau sendiri-sendiri terhadap variabel terikat. Pengujiannya dilihat dalam tabel Coeffcience kolom Significance (Sig) jika tingkat penggunaan signifikansi sebesar 5\% probalitas nilai $\mathrm{t}<0.05$ sehingga dikatakan terdapat pengaruh antara kedua variabel secara parsial namun sebaliknya jika probalitas $>0,05$ tidak ada pengaruh yang signifikan antara kedua variabel.

1. Jika $\mathrm{t}_{\text {hitung }}>\mathrm{t}_{\text {tabel }}$, maka $\mathrm{H}_{\mathrm{o}}$ ditolak dan $\mathrm{H}_{1}$ diterima.

2. Jika $t_{\text {hitung }}<\mathrm{t}_{\text {tabel}}$, maka $\mathrm{H}_{\mathrm{o}}$ diterima dan $\mathrm{H}_{1}$ ditolak.

\section{HASIL PENELITIAN DAN PEMBAHASAN}

Hasil pretest kuesioner untuk uji validitas, dilakukan dengan cara membandingkan antara rhitung dengan rtabel pada signifikan 5\% dengan rumus : (df) $=\mathrm{N}-2$, dimana $\mathrm{N}$ (responden pretest) sebanyak 15 responden. Sehingga diketahui pada penelitian ini derajat kebebasan (df) $=15-2=13$, didapat rtabel $=0,5140$. Menurut (Arikunto, 2006:72), suatu instrumen akan dikatakan valid apabila rhitung $\geq$ rtabel, dan sebaliknya.

Tabel 2. Hasil Uji Validitas

\begin{tabular}{lcccc}
\hline \multicolumn{1}{c}{ Variabel } & $\begin{array}{c}\text { Item } \\
\text { Pertanyaan }\end{array}$ & $\begin{array}{c}\text { Pearson Correlation } \\
\text { (R_hitung) }\end{array}$ & R_tabel & Keterangan \\
\hline Peraturan Perpajakan & X1.2 & 0,763 & 0,514 & Valid \\
(X1) & X1.3 & 0,769 & 0,514 & Valid \\
& X1.4 & 0,763 & 0,514 & Valid \\
& X1.5 & 0,823 & 0,514 & Valid \\
& X1.6 & 0,800 & 0,514 & Valid \\
& X1.7 & 0,850 & 0,514 & Valid \\
& X1.8 & 0,845 & 0,514 & Valid \\
Sosialisasi & X1.9 & 0,650 & 0,514 & Valid \\
(X2) & X1.10 & 0,601 & 0,514 & Valid \\
& X2.1 & 0,736 & 0,514 & Valid \\
& X2.2 & 0,884 & 0,514 & Valid \\
& X2.3 & 0,856 & 0,514 & Valid \\
& X2.4 & 0,769 & 0,514 & Valid \\
X2.5akan & 0,902 & 0,514 & Valid \\
Sistem & X2.6 & 0,686 & 0,514 & Valid \\
Perpajakan (X3) & X2.7 & 0,726 & 0,514 & Valid \\
& X2.9 & 0,753 & 0,514 & Valid \\
& X2.10 & 0,873 & 0,514 & Valid \\
& X2.11 & 0,682 & 0,514 & Valid \\
& X2.12 & 0,814 & 0,514 & Valid \\
& X2.13 & 0,920 & 0,514 & Valid \\
& X3.1 & 0,718 & 0,514 & Valid \\
& & 0,814 & 0,514 & Valid \\
& & 0,926 & 0,514 & Valid \\
& & 0,579 & 0,514 & Valid \\
& & 0,509 & 0,514 & Tidak \\
& & & &
\end{tabular}

DOI: http://dx.doi.org/10.33021/jaaf.v3i2.939 


\begin{tabular}{lcccc} 
& & & Valid \\
& X3.5 & 0,895 & 0,514 & Valid \\
X3.6 & 0,947 & 0,514 & Valid \\
X3.7 & 0,882 & 0,514 & Valid \\
X3.8 & 0,842 & 0,514 & Valid \\
X3.9 & 0,834 & 0,514 & Valid \\
X3.10 & 0,811 & 0,514 & Valid \\
X3.11 & 0,892 & 0,514 & Valid \\
X3.12 & 0,820 & 0,514 & Valid \\
Kemauan & X3.13 & 0,935 & 0,514 & Valid \\
Tax Amnesty (Y) & X3.14 & 0,883 & 0,514 & Valid \\
& X3.15 & 0,778 & 0,514 & Valid \\
& Y.1 & 0,835 & 0,514 & Valid \\
& Y.2 & 0,900 & 0,514 & Valid \\
Y.3 & 0,700 & 0,514 & Valid \\
& Y.4 & 0,757 & 0,514 & Valid \\
& Y.5 & 0,784 & 0,514 & Valid \\
Y.6 & 0,897 & 0,514 & Valid \\
Y.7 & 0,860 & 0,514 & Valid \\
Y.8 & 0,908 & 0,514 & Valid \\
Y.9 & 0,936 & 0,514 & Valid \\
Y.10 & 0,769 & 0,514 & Valid \\
Y.11 & 0,899 & 0,514 & Valid \\
Y.12 & 0,942 & 0,514 & Valid \\
Y.13 & 0,846 & 0,514 & Valid \\
Y.14 & 0,715 & 0,514 & Valid \\
Y.15 & 0,784 & 0,514 & Valid \\
Y.16 & 0,819 & 0,514 & Valid \\
\hline
\end{tabular}

Sumber: Data SPSS yang Diolah, 2019

Sesuai dengan hasil olah data pretest diatas dengan menggunakan SPSS, diperoleh bahwa hampir seluruh butir pernyataan untuk variabel independend dan dependen memiliki status valid, karena nilai $r_{\text {hitung }}>r_{\text {tabel }}$ sebesar 0,514 , kecuali pada variabel kepercayaan terhadap sistem perpajakan pada butir pernyataan (X3.4) memiliki status tidak valid, karena nilai $r_{\text {hitung }}$ $<\mathrm{r}_{\text {tabel }}$ sebesar 0,514, sehingga pernyataan tersebut tidak digunakan pada saat pengumpulan data.

Uji reliabilitas dilakukan dengan membandingkan hasil hitung nilai Cronbach's Alpha, yaitu apabila setiap variabel memiliki nilai Cronbach's Alpha diatas 0,60 maka variabel tersebut dapat dinyatakan reliabel, dan sebaliknya (Sugiyono, 2011:73).

Tabel 3. Hasil Uji Reliabilitas

\begin{tabular}{lcc}
\hline \multicolumn{1}{c}{ Variabel } & Cronbach'c Alpha & Keterangan \\
\hline Peraturan Perpajakan (X1) & 0,906 & Reliabel \\
Sosialisasi Perpajakan (X2) & 0,951 & Reliabel \\
Kepercayaan terhadap Sistem Perpajakan (X3) & 0,966 & Reliabel \\
Kemauan dalam Melaksanakan Tax Amnesty (Y) & 0,968 & Reliabel \\
\hline
\end{tabular}

Sumber: Data SPSS yang Diolah, 2019

DOI: http://dx.doi.org/10.33021/jaaf.v3i2.939 
Sesuai dengan hasil dari pengujian reliabilitas di atas, dapat dilihat bahwa seluruh variabel adalah reliabel atau handal, karena masing-masing variabel memiliki nilai Cronbach'c Alpha yang lebih besar dari 0,60.

\section{Uji Asumsi Klasik}

Tabel 4. Hasil Uji Normalitas

\begin{tabular}{lc}
\hline & Unstandardized Residual \\
\hline Test Statistic & 0,077 \\
Asymp. Sig. (2-tailed) & 0,105 \\
\hline
\end{tabular}

Sumber: Data SPSS yang Diolah, 2019

Berdasarkan Tabel 4 hasil uji normalitas menunjukkan bahwa data pada model regresi telah memenuhi asumsi data terdistribusi secara normal, karena memiliki nilai Asymp.sig sebesar 0,105 yang lebih besar dari 0,05 sehingga dapat diambil kesimpulan bahwa seluruh data dalam penelitian ini berdistribusi normal.

Tabel 5. Hasil Uji Multikolinearitas

\begin{tabular}{lccc}
\hline \multicolumn{1}{c}{ Model } & \multicolumn{2}{c}{ Collinearity Statistics } & \multirow{2}{*}{ Keterangan } \\
& Tolerance & VIF & \\
\hline Peraturan Perpajakan (X1) & 0,596 & 1,678 & Bebas Multikolinearitas \\
Sosialiasi Perpajakan (X2) & 0,510 & 1,960 & Bebas Multikolinearitas \\
Kepercayaan terhadap & & & \\
Sistem Perpajakan (X3) & 0,612 & 1,634 & Bebas Multikolinearitas \\
\hline
\end{tabular}

Sumber: Data SPSS yang Diolah, 2019

Berdasarkan Tabel 5 hasil uji multikolinearitas didapat bahwa keseluruhan variabel independen memilki nilai tolerance $>0,1$ dan nilai VIF $\leq 10$ dengan nilai tolerance dan VIF untuk variabel peraturan perpajakan (X1) sebesar 0.596 dan 1.678, variabel sosialisasi perpajakan (X2) sebesar 0.510 dan 1.960, variabel kepercayaan terhadap sistem perpajakan (X3) sebesar 0.612 dan 1.634. Sehingga dapat disimpulkan bahwa tidak terjadi multikolinearitas antar variabel independen.

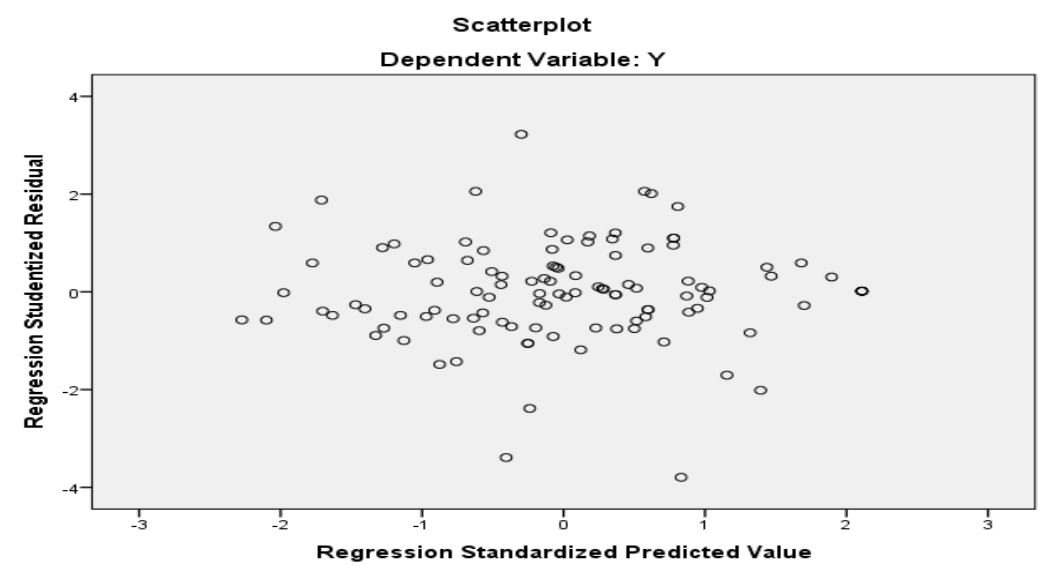

Gambar 2. Hasil Uji Heteroskedastisitas

DOI: http://dx.doi.org/10.33021/jaaf.v3i2.939 
Hasil pengujian pada gambar 1 dikatakan model regresi baik karena data penelitian setelah dilakukan uji heterokedastisitas memperoleh data yang menyebar dan tidak membentuk pola maka pada data tersebut tidak mengalami heterokedastisitas.

\section{Analisis Statistik Deskriptif}

Tabel 6. Hasil Uji Statistik Deskriptif

\begin{tabular}{lccccc}
\hline & N & Minimum & Maximum & Mean & $\begin{array}{c}\text { Std. } \\
\text { Deviation }\end{array}$ \\
\hline $\begin{array}{l}\text { Peraturan Perpajakan (X1) } \\
\begin{array}{l}\text { Sosialisasi Perpajakan } \\
\text { (X2) }\end{array}\end{array}$ & 110 & 25 & 50 & 39,32 & 5,297 \\
$\begin{array}{l}\text { Kepercayaan terhadap } \\
\text { Sistem Perpajakan (X3) }\end{array}$ & 110 & 31 & 65 & 50,60 & 7,196 \\
$\begin{array}{l}\text { Kemauan dalam } \\
\text { Melaksanakan Tax }\end{array}$ & 110 & 39 & 70 & 53,57 & 7,851 \\
$\begin{array}{l}\text { Amnesty (Y) } \\
\text { Valid N (listwise) }\end{array}$ & 110 & 43 & 80 & 62,21 & 9,608 \\
\hline
\end{tabular}

Sumber: Data SPSS yang Diolah, 2019

Sesuai dengan Tabel 6 diatas diketahui bahwa variabel Peraturan Perpajakan (X1) memiliki nilai minimum dan maksimum berada pada rentang antara 25 sampai 50, nilai mean sebesar 39,32 yang artinya responden telah menjawab pada pilihan yang mendekati nilai maksimum yaitu 50, dan nilai standar deviasinya (tingkat sebaran datanya) sebesar 5,297. Variabel Sosialisasi Perpajakan (X2) memiliki nilai minimum dan maksimum berada pada kisaran antara 31 sampai 65, nilai mean pada data tersebut sebesar 50,60 yang artinya responden telah menjawab pada pilihan yang mendekati nilai maksimum yaitu 65 , dan nilai standar deviasinya (tingkat sebaran datanya) sebesar 7,196. Variabel Kepercayaan terhadap Sistem Perpajakan (X3) memiliki nilai minimum dan maksimum berada pada kisaran antara 39 sampai 70, nilai mean pada data tersebut sebesar 53,57 yang artinya responden telah menjawab pada pilihan yang mendekati nilai maksimum yaitu 50, dan nilai standar deviasinya (tingkat sebaran datanya) sebesar 7,851.Variabel Kemauan dalam Melaksanakan Tax Amnesty (Y) memiliki nilai minimum dan maksimum berada pada kisaran antara 43 sampai 80, nilai mean pada data tersebut sebesar 62,21 yang artinya responden telah menjawab pada pilihan yang mendekati nilai maksimum yaitu 80 , dan nilai standar deviasinya (tingkat sebaran datanya) sebesar 9,608.

\section{Analisis Regresi Linear Berganda}

Tabel 7. Hasil Regresi Linear Berganda

\begin{tabular}{cccccc}
\hline Model & $\begin{array}{c}\text { Unstandardized } \\
\text { Coefficients }\end{array}$ & $\begin{array}{c}\text { Unstandardized } \\
\text { Coefficients }\end{array}$ & & \\
\hline B & Std. & Beta & T & Sig.
\end{tabular}

DOI: http://dx.doi.org/10.33021/jaaf.v3i2.939 


\begin{tabular}{lccccc}
\hline & \multicolumn{3}{c}{ Error } & & \\
(Constant) & 0,333 & 0,287 & & 1,158 & 0,250 \\
$\begin{array}{l}\text { Peraturan Perpajakan } \\
\text { (X1) }\end{array}$ & 0,181 & 0,085 & 0,160 & 2,117 & 0,037 \\
$\begin{array}{l}\text { Sosialisasi Perpajakan } \\
\text { (X2) }\end{array}$ & 0,147 & 0,086 & 0,138 & 1,698 & 0,092 \\
$\begin{array}{l}\text { Kepercayaan terhadap } \\
\text { Sistem Perpajakan (X3) }\end{array}$ & 0,642 & 0,079 & 0,609 & 8,182 & 0,000 \\
\hline
\end{tabular}

Sumber: Data SPSS yang Diolah 2019

Sesuai dengan Tabel 7 diatas diperoleh persamaan regresinya adalah sebagai berikut:

$$
\begin{aligned}
& \mathbf{Y}=\boldsymbol{\alpha}+\boldsymbol{\beta}_{1} \mathbf{X}_{\mathbf{1}}+\boldsymbol{\beta}_{\mathbf{2}} \mathbf{X}_{\mathbf{2}}+\boldsymbol{\beta}_{\mathbf{3}} \mathbf{X}_{\mathbf{3}}+\boldsymbol{\varepsilon} \ldots . . \text { (I) } \\
& \mathrm{Y}=0.333+0.181 \mathrm{X} 1+0.147 \mathrm{X} 2+0.642 \mathrm{X} 3+0,287
\end{aligned}
$$

Nilai konstanta sebesar 0.333 menunjukkan bahwa jika variabel-variabel independen nilainya 0 , maka variabel dependen nilainya sebesar 0.333 . Koefisien regresi untuk variabel Peraturan Perpajakan memiliki pengaruh yang signifikan dengan nilai sebesar 0.181 atau senilai dengan $18.1 \%$ artinya variabel Peraturan Perpajakan (X1) memiliki pengaruh bagi Kemauan dalam Melaksanakan Tax Amnesty, apabila Peraturan Perpajakan meningkat maka Kemauan dalam Melaksanakan Tax Amnesty ikut meningkat dan sebaliknya. Koefisien regresi untuk variabel Sosialisasi Perpajakan memiliki pengaruh yang signifikan dengan nilai sebesar 0.147 atau senilai dengan $14.7 \%$ artinya variabel Sosialisasi Perpajakan (X2) memiliki pengaruh bagi Kemauan dalam Melaksanakan Tax Amnesty, apabila Sosialisasi Perpajakan meningkat maka Kemauan dalam Melaksanakan Tax Amnesty ikut meningkat dan sebaliknya. Koefisien regresi untuk variabel Kepercayaan terhadap Sistem Perpajakan memiliki pengaruh yang signifikan dengan nilai sebesar 0.642 atau senilai dengan $64.2 \%$ artinya variabel Kepercayaan terhadap Sistem Perpajakan (X3) memiliki pengaruh bagi Kemauan dalam Melaksanakan Tax Amnesty, apabila Kepercayaan terhadap Sistem Perpajakan meningkat maka Kemauan dalam Melaksanakan Tax Amnesty ikut meningkat dan sebaliknya.

\section{Uji Koefisien Determinasi $\left(R^{2}\right)$}

Tabel 8. Hasil Uji R-Square (Uji Determnasi)

\begin{tabular}{ccccr}
\hline Model & $\mathrm{R}$ & $\begin{array}{c}\mathrm{R} \\
\text { Square }\end{array}$ & $\begin{array}{c}\text { Adjusted R } \\
\text { Square }\end{array}$ & $\begin{array}{c}\text { Std. Error of } \\
\text { the Estimate }\end{array}$ \\
\hline 1 & 0,801 & 0,641 & 0,631 & 0,09432 \\
\hline \multicolumn{5}{c}{ Sumber: Data SPSS yang Diolah 2019 }
\end{tabular}

Sesuai dengan Tabel 8 diatas diketahui bahwa nilai Adjusted R Square sebesar 0.631. Hal ini berarti bahwa seluruh variabel independen (X) yaitu peraturan perpajakan, sosialisasi perpajakan, dan kepercayaan terhadap sistem perpajakan memiliki kontribusi secara bersamasama sebesar $63.1 \%$ terhadap variabel dependen (Y) yaitu kemauan dalam melaksanakan tax amnesty, sedangkan sisanya sebesar $36.9 \%$ dijelaskan oleh faktor lain diluar dari penelitian ini. Hal ini berarti pengaruh antar 3 variabel kuat karena semakin besar angka adjusted $R$ Square maka semakian kuat pula pengaruh 3 variabel tersebut. 


\section{Uji Parsial (Uji T)}

Tabel 9. Hasil Uji Statistik T

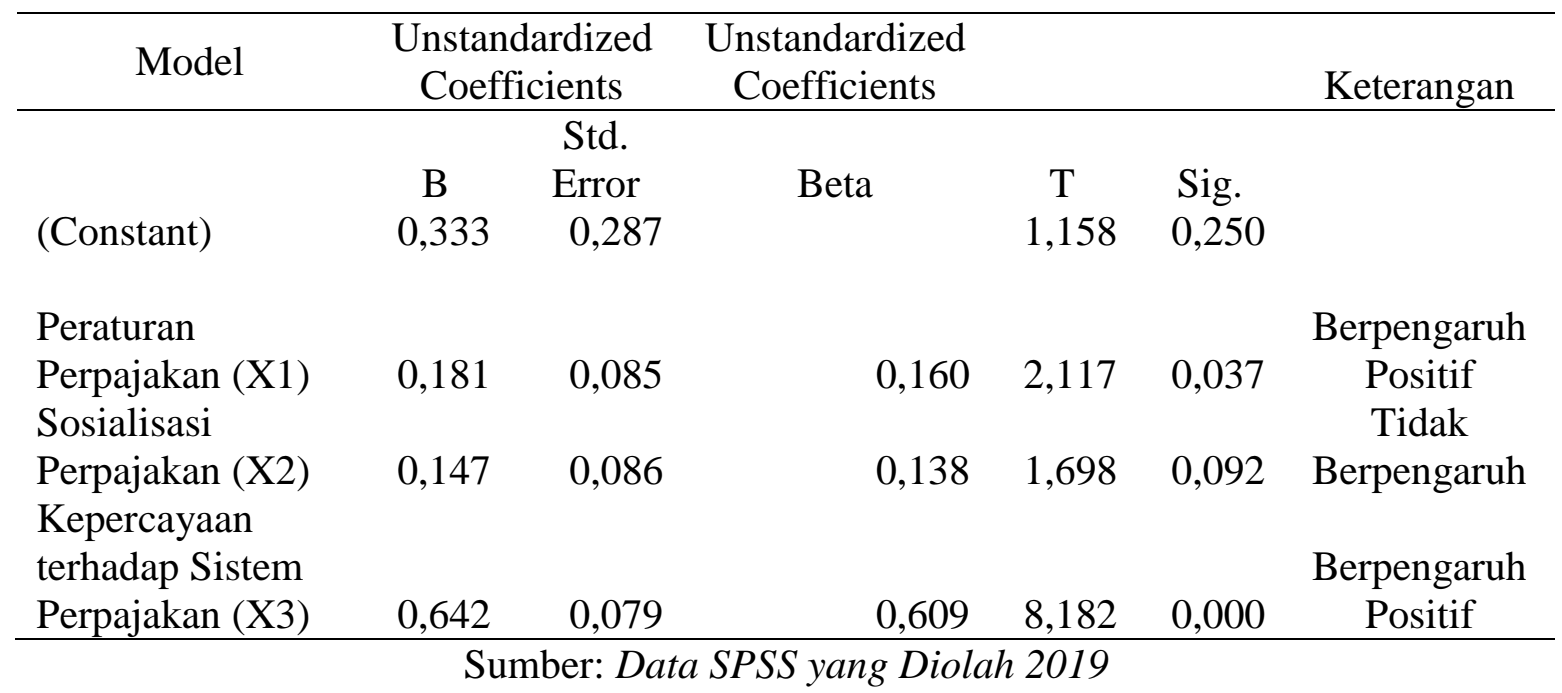

Sesuai dengan Tabel 9 variabel peraturan perpajakan (X1) didapatkan $t_{\text {hitung }}$ sebesar 2.117 dengan nilai signifikan sebesar 0.037 dan nilai $t_{\text {tabel }}$ sebesar 1.982 sehingga nilai $t_{\text {hitung }}>t_{\text {tabel }}$ $(2.117>1.982)$ atau sig < a $(0,037<0.05)$, hal ini berarti bahwa variabel peraturan perpajakan berpengaruh positif terhadap kemauan wajib pajak dalam melaksanakan tax amnesty di kabupaten bekasi. Dengan kata lain Ho ditolak dan Ha diterima, sehingga hipotesis pertama diterima.

Variabel sosialisasi perpajakan (X2) didapatkan $t_{\text {hitung }}$ sebesar 1.698 dengan nilai signifikan sebesar 0.092 dan nilai $t_{\text {tabel }}$ sebesar 1.982 sehingga nilai $t_{\text {hitung }}<t_{\text {tabel }},(1,698<$ 1.982) atau sig > a $(0,092>0.05)$, hal ini berarti bahwa variabel sosialisasi perpajakan tidak berpengaruh terhadap kemauan wajib pajak dalam melaksanakan tax amnesty di Kabupaten Bekasi. Dengan kata lain $\mathrm{H}_{0}$ diterima dan $\mathrm{H}_{1}$ ditolak, sehingga hipotesis pertama tidak diterima.

Variabel kepercayaan terhadap sistem perpajakan (X3) didapatkan $\mathrm{t}_{\text {hitung }}$ sebesar 8.182 dengan nilai signifikan sebesar 0.000 dan nilai $t_{\text {tabel }}$ sebesar 1.982 sehingga nilai $t_{\text {hitung }}>t_{\text {tabel }}$, $(8.182>1,982)$ atau sig < a $(0,000<0.05)$, hal ini berarti bahwa variabel kepercayaan terhadap sistem perpajakan berpengaruh positif terhadap kemauan wajib pajak dalam melaksanakan tax amnesty di kabupaten bekasi. Dengan kata lain Ho ditolak dan Ha diterima, sehingga hipotesis pertama diterima.

\section{Pembahasan}

Berdasarkan hasil pengujian yang telah dilakukan menunjukan bahwa peraturan perpajakan berpengaruh kemauan wajib pajak dalam melaksanakan tax amnesty karena semakin mudahnya kalimat, isi dan tata cara yang tercantum dalam peraturan perpajakan maka akan memberikan kemudahan bagi wajib pajak dalam melaksanakan setiap programprogram perpajakan khususnya program tax amnesty. Peraturan perpajakan akan dapat efektif jika wajib pajak dapat memahami peraturan perpajakan dengan baik dan mampu menerapkannya tanpa merasa kebingungan. Peraturan perpajakan yang telah di sosialisasikan terlebih dahulu akan memberikan pemahaman bagi wajib pajak sehingga wajib pajak mudah menerapkan dan melaksanakannya. Jika pengetahuan wajib pajak mengenai 
peraturan perpajakan rendah, maka kemauan dalam melaksanakan tax amnesty juga rendah karena wajib pajak tidak mampu memahami isi dan tata cara perpajakan yang tercantum di peraturan perpajakan.

Berdasarkan hasil pengujian yang telah dilakukan menunjukan bahwa sosialisasi perpajakan tidak berpengaruh terhadap kemauan wajib pajak dalam melaksanakan tax amnesty, karena sosialisasi pajak nyatanya masih belum rutin dilaksanakan khususnya bagi calon-calon wajib pajak, akibatnya tidak sedikit wajib pajak yang tidak mendapatkan sosialisasi perpajakan, sehingga kurangnya pengetahuan wajib pajak dalam setiap programprogram pemerintah serta pengetahuan atas peraturan-peraturan baru yang ditetapkan. Sosialisasi perpajakan harus rutin dilakukan untuk meningkatkan pengetahuan wajib pajak, dan sebaiknya materi atau informasi perpajakan yang disampaikan oleh Kantor Pelayanan Perpajakan (KPP) dalam kegiatan sosialisasi agar dibuat lebih rinci, baik dari segi pelaksanaan materiil, formil, teoritis, serta praktisnya, terutama pada saat adanya peraturanperaturan perpajakan terbaru, atau pada saat adanya program-program pemerintah yang terkait dengan perpajakan.

Ketidakpahaman wajib pajak terhadap materi perpajakan yang disampaikan dapat disebabkan karena materi perpajakan yang disampaikan oleh fiskus yang masih belum memberikan pemahaman bagi wajib pajak, karena materi yang disampaikan tidak menarik dan membosankan, seharusnya Kantor Pelayanan Perpajakan (KPP) lebih memperhatikan keterampilan dan kecakapan pembicara atau fiskus yang harus menguasai materi dan dapat menyampaikan materi tersebut dengan bahasa yang sesederhana mungkin sehingga informasi dapat diterima dengan baik, dan materi yang disampaikan jangan hanya pokok-pokok materi tetapi juga penjelasan dan diusahakan pembicara atau fiskus dapat menambahkan improvisasi agar sosialisasi yang dilakukan menjadi lebih santai dan tidak membosankan. Perlu juga diadakannya pelatihan dan seminar secara berkala oleh Dirjen Pajak agar semakin memberikan pemahaman kepada wajib pajak dalam perpajakan sehingga semakin sadar wajib pajak akan pentingnya pajak.

Berdasarkan hasil pengujian yang telah dilakukan, menunjukkan bahwa kepercayaan terhadap sistem perpajakan berpengaruh terhadap kemauan wajib pajak dalam melaksanakan tax amnesty sehingga dapat diartikan bahwa semakin tinggi tingkat kepercayaan terhadap sistem perpajakan maka kemauan wajib pajak dalam melaksanakan tax amnesty juga semakin tinggi. Kepercayaan terhadap sistem perpajakan akan mendorong kemauan wajib pajak untuk melaksanakan tax amnesty apabila Dirjen Pajak telah menjamin kesetaraan hukum antara wajib pajak dan Pegawai Pajak dalam pelaksanaan hak dan kewajiban perpajakan Wajib, menjamin hak yang sama dalam memperoleh informasi yang disediakan oleh aparat pajak bagi setiap wajib pajak, dan menjamin penerapan sanksi hukum yang sama dan adil kepada semua pihak yang terlibat dalam pelanggaran yang dilakukan.

Tingkat kepercayaan terhadap sistem perpajakan yang tinggi memicu munculnya komitmen yang kuat dan taat terhadap peraturan yang ada, termasuk dalam perpajakan. Sistem perpajakan yang adil dan transparan akan meningkatkan kepercayaan terhadap sistem perpajakan, sehingga kesadaran perpajakan pada masyarakat akan tinggi yang akhirnya mendorong meningkatnya kemauan dalam melaksanakan program-program pemerintah serta mendorong wajib pajak agar taat pajak.

DOI: http://dx.doi.org/10.33021/jaaf.v3i2.939 


\section{KESIMPULAN}

Berdasarkan hasil analisis dan pembahasan di atas, maka dapat disimpulkan bahwa: (1) Peraturan Perpajakan berpengaruh signifikan positif terhadap kemauan wajib pajak dalam melaksanakan tax amnesty sehingga $\mathrm{H}_{1}$ diterima. Kesimpulan ini ditunjukkan dari hasil uji $\mathrm{t}$ yang diperoleh bahwa nilai $t_{\text {hitung }} 2.117>$ nilai $t_{\text {tabel }} 1.982$ dan dengan tingkat nilai signifikansi $0.037<0.05$. (2) Sosialisasi Perpajakan berpengaruh signifikan negatif terhadap kemauan wajib pajak dalam melaksanakan tax amnesty sehingga $\mathrm{H}_{1}$ ditolak. Kesimpulan ini ditunjukkan dari hasil analisis yang diperoleh bahwa nilai $t_{\text {hitung }} 1.689<$ nilai $t_{\text {tabel }} 1.982$ dan dengan tingkat nilai signifikansi $0.092>0.05$; dan (3) Kepercayaan terhadap sistem perpajakan berpengaruh signifikan positif terhadap kemauan wajib pajak dalam melaksanakan tax amnesty sehingga $\mathrm{H}_{1}$ diterima. Kesimpulan ini ditunjukkan dari hasil analisis yang diperoleh bahwa nilai $t_{\text {hitung }} 8.182>$ nilai $t_{\text {tabel }} 1.982$ dan dengan tingkat nilai signifikansi $0.000<0.05$.

Saran dari penelitian ini bagi penelitian selanjutnya diharapkan dapat menambahkan variabel independen lainnya yang mendorong kemauan wajib pajak dalam melaksanakan tax amnesty dan dapat menambahkan variabel moderating atau intervening yang bertujuan untuk mengetahui variabel-variabel lain yang dapat mempengaruhi variabel dependen.

Penelitian ini memiliki beberapa keterbatasan yakni : (1) jumlah sampel wajib pajak yang digunakan dalam penelitian ini hanya 110 responden karena ruang lingkup yang sempit sehingga banyaknya jumlah sampel belum dapat mewakili kondisi yang sebenarnya; (2) variabel yang diteliti hanya 3 variabel yakni peraturan perpajakan, sosialisasi perpajakan dan kepercayaan terhadap sistem perpajakan; (3) penelitian ini belum membedakan antara responden yang telah melaksanakan tax amnesty dan responden yang tidak melaksanakan tax amnesty.

\section{DAFTAR PUSTAKA}

Arfan, \& Lubis, I. (2011). Akuntansi Keperilakuan. Jakarta: Salemba Empat.

Arikunto, S. (2013). Prosedur Penelitian: suatu Pendekatan Praktik. Jakarta: Rineka Cipta.

Ariyanti, F. (2017, February 23). 2-juta-wp-tak-lapor-pajak-benar-hanya-659-ribu-ikut-taxamnesty. Diambil kembali dari Liputan 6: https://www.liputan6.com

Awlia, K. M., \& Siringoringo, W. (2019). Pengaruh Pengetahuan dan Penerapan Perppu Nomor 1 Tahun 2017 tentang Akses Informasi Keuangan terhadap Kepatuhan Wajib Pajak (Studi Empiris Wajib Pajak Orang Pribadi di Cikarang Utara). JAAF (Journal of Applied Accounting and Finance), 3(1), 13-26.

Dwijayanti, Y., \& Hamidah. (2017). Niat dan Perilaku Wajib Pajak Orang Pribadi Mengikuti Program Tax Amnesty (Studi Fenomenologi). Jurnal Akuntansi Universitas Jember, $11-15$.

Ferdinand, A. (2006). Metode Penelitian Manajemen. Semarang: Badan Penerbit Universitas Diponegoro.

Ghozali, I. (2013). Aplikasi Analisis Multivariate dengan Program SPSS. Semarang: Badan Penerbit universitas Diponegoro.

Hardiningsih, P., \& Yulianawati, N. (2011). Faktor-Faktor yang Mempengaruhi Kemauan Membayar Pajak. Dinamika Keuangan dan Perbankan, 3(1), 126-142. 
Huslin, D., \& Ngadiman. (2015). Pengaruh Sunset policy, Tax Amnesty, dan Sanksi PajakTerhadap Kepatuhan Wajib Pajak (Studi Empiris di Kantor Pelayanan Pajak Pratama. Jurnal Akuntansi, 14(2), 225-241.

Kirana, A., \& Moordiningsih. (2010). Studi Korelasi Efikasi Diri dan Dukungan Sosial dengan Prestasi Akademik: Telaah pada Siswa Perguruan Tinggi. Indigenous Jurrnal Ilmiah Berskala Psikologi, 12(1), 47-54.

Rachman, F. F. (2017, Mei 5). Dana Repatriasi Tax Amnesty Dipakai untuk Apa? Ini Kata Pengusaha. Diambil kembali dari https://finance.detik.com/: https://finance.detik.com

Rahayu, P. A. (2016). Pengaruh Sosialisasi Peraturan Perpajakan, Pelayananan Account Representative, dan Pemeriksaan PPN LB Restitusi Setelah Modernisasi Terhadap Kepuasan. Jurnal Akuntansi, 8(2), 175-202.

Rantung, T. A. (2009). Dampak Sunset Policy Terhadap Faktor-Faktor Yang Mempengaruhi Kemauan Membayar Pajak (Studi Pada Wajib Pajak Orang pribadi Pelaku Usaha di Wilayah KPP Pratama Salatiga). Simposium Nasional Perpajakan II Madura.

Reskino, Rini , \& Novitasari. (2014). Persepsi Mahasiswa Akuntansi Mengenai Penggelapan Pajak. Jakarta: Fakultas Ekonomi dan Bisnis UIN Syarif Hidayatullah. Jurnal InFestasi, 10(1), 49-63.

Robbins, S. P., \& Timothy, A. (2015). Organizational behaviour. State America: Pearson.

Rohmawati, Lusia, Prasetyono, \& Rimawati , Y. (2013). Pengaruh Sosialisasi dan Pengetahuan Perpajakan terhadap Tingkat Kesadaran dan Kepatuhan Wajib Pajak (Studi pada Wajib Pajak Orang Pribadi yang Melakukan Kegiatan Usaha dan Pekerjaan Bebas pada KPP Pratama Gresik Utara). Simposium Nasional Perpajakan II Madura.

Sarjono, H., \& Julianita, W. (2012). SPSS VS LISREL: Sebuah pengantar, Aplikasi Untuk Riset. Jakarta: Penerbit Salemba Empat.

Sekaran, U. (2006). Research Method for Business. Jakarta: Salemba Empat.

Sembiring, L. J. (2017). Kurang Sosialisasi, Penyebab Tebusan Tax Amnesty Tak Capai Target. Retrieved November 16, 2018, from https:// economy. okezone.com/ read/ 2017/ 04/ 01/ 20/ 1656152/ kurang-sosialisasi-penyebab-tebusan-tax-amnesty-takcapai-target.

Sugiyono. (2012). Metode Penelitian Kuantitatif, Kualitatif, dan R\&D. Bandung: PT Alfabeta.

Trisnasari, A. S., Edy, S., \& Trisna, H. (2017). Pengaruh Kesadaran Wajib Pajak, Sosialisasi Perpajakan dan Pengetahuan Perpajakan terhadap Kemauan Wajib Pajak dalam Mengikuti Program Tax Amnesty. e Journal S1 Ak universitas Pendidikan Ganesha, 7(1), 1-11.

Winerungan, O. L. (2013). Sosialisasi Perpajakan, Pelayanan Fiskus dan Sanksi Perpajakan terhadap Kepatuhan WPOP di KPP Manado dan KPP Bitung. Jurnal Emba, 1(3), 960970.

Yani, N. K., \& Noviari, N. (2017). Faktor-Faktor yang Mempengaruhi Kemauan Wajib Pajak Menjadi Peserta Amnesti Pajak. E-Jurnal Akuntansi Universitas Udayana, 20(1), 585614.

Yilmaz, A., \& Atalay, C. G. (2009). A Theoretical Analyze on The Concept of Trust in Organisational Life. European Journal of Social Sciences, 8(2), 341-352. 